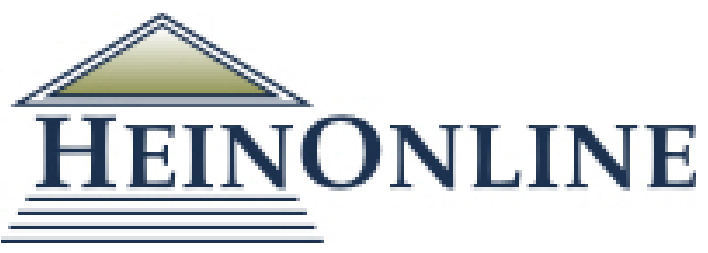

Content downloaded/printed from

HeinOnline

Mon Jan 27 12:05:32 2020

Citations:

Bluebook 20th ed.

79 J. Crim. L. 385 (2015).

ALWD 6th ed.

79 J. Crim. L. 385 (2015).

APA 6th ed.

(2015). Journal of Criminal Law, 79(6), 385-394.

Chicago 7th ed.

, "," Journal of Criminal Law 79, no. 6 (December 2015): 385-394

OSCOLA 4th ed.

, " (2015) 79 J Crim L 385

-- Your use of this HeinOnline PDF indicates your acceptance of HeinOnline's Terms and Conditions of the license agreement available at https://heinonline.org/HOL/License

-- The search text of this PDF is generated from uncorrected OCR text.

-- To obtain permission to use this article beyond the scope of your license, please use: Copyright Information

Use QR Code reader to send PDF to your smartphone or tablet device

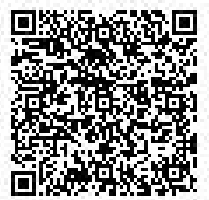




\section{Court of Appeal}

The Journal of Criminal Law 2015, Vol. 79(6) 385-394

(C) The Author(s) 2015

Reprints and permissions:

sagepub.co.uk/journalsPermissions.nav

DOI: $10.1 \mid 77 / 00220183$ |56/9268

clj.sagepub.com

OSAGE

\section{Sexual Offence Complainants and Credibility: Why Virginity Testing is Pointless $R v L$ [2015] EWCA Crim 74I}

\section{Keywords}

Rape shield, evidence of complainant's previous sexual history, Criminal Cases Review Commission, rape, sexual assault, medical evidence of hymenal disruption

\section{Facts}

On a reference from the Criminal Cases Review Commission (CCRC) the appellant appealed his convictions for three counts of sexual assault and one charge of rape.

The complainant, M, came to England from Nigeria at the age of 15 . She lived with her half-sister and her half-sister's husband (the appellant) in South London. Within a year of living with them she made allegations of sexual assault and rape against the appellant to a counsellor at her school.

The prosecution case was that $M$ had been subjected to progressively serious sexual assaults, leading ultimately to rape. The defence was denial: $M$ was lying, perhaps out of a desire to be rehoused.

In the first trial the appellant was convicted of three counts of sexual assault. The jury could not agree on verdicts on six other counts of sexual assault and one charge of rape. In January 2008 the appellant was convicted on a retrial of the rape offence. In both trials the complainant asserted she was a virgin at the time of the rape. The examining doctor's witness statement, which was read to the jury at both trials, indicated that the complainant's hymen was disrupted in three places. The examining doctor could not say when the complainant had first had sexual intercourse, beyond that it had been more than 72 hours previously.

At the retrial on the rape charge the prosecution asserted that the evidence of hymenal penetration had resulted from the rape by the appellant. This stance was a change to that adopted by the prosecution at the first trial, where the medical evidence of hymenal damage had not been argued to be solely attributable to the rape by the appellant. The new approach was consistent with the complainant's statement that she had told the appellant that he had taken her virginity, that he had apologised and said he had not known that she was a virgin. Her evidence was that she bled for three days afterwards. However, the increased focus on the issue of the hymenal injury ultimately became crucial to outcome of this appeal.

In November 2011 the CCRC referred the case to the Court of Appeal based on fresh evidence: a previously undisclosed note made by an assistant social worker who had accompanied the complainant to a medical examination. The note stated that the complainant had reported at that meeting that she had been raped as a child. That appeal was dismissed ([2012] EWCA Crim 1961), the court holding that the note was likely to be inaccurate because the examining doctor's statement, which was likely to be a more accurate record of the conversation, did not mention any assertion of childhood rape. Furthermore the court held that there was stronger evidence on the issue and that the note would not have significantly improved the defence's armoury.

The present appeal was a second reference by the CCRC on the basis that new evidence had been disclosed: original notes made by the examining doctor and her colleague, which appeared to confirm 
that the complainant reported having been raped as a child. The examining doctor clarified that the hymenal injuries could have been caused by the earlier incident and '[could] not medically be attributed to one incident rather than another' (at [30]). The CCRC argued that the fresh evidence rendered the medical evidence relating to the damage to M's hymen neutral and was capable of undermining her credibility, and gave rise to a real possibility that the convictions would not be upheld.

The Crown accepted that a jury might conclude that the complainant was raped at the age of five and this would account for the damage to the hymen. It accepted that this evidence might affect M's credibility in relation to the rape charge since her denial when asked whether she had ever had intercourse 'might appear to be an attempt to bolster the significance of the medical evidence' (at [33]).

The Crown argued that the fresh evidence did not affect the safety of the sexual assault convictions, since the jury was satisfied of guilt of sexual assault in the first trial. The first jury was clearly alive to the weaknesses in the complainant's evidence, as they were not able to agree on six counts of sexual assault and the charge of rape. However, they did agree upon verdicts on three specimen counts of relatively minor sexual assault. Therefore the evidence that $\mathrm{M}$ was raped at the age of five did not detract significantly from her evidence regarding the sexual assault. Similarly, although the defence could have argued that $\mathrm{M}$ had lied about being a virgin to bolster evidence of the rape, there was no motive to tell such lies to bolster any evidence of sexual assault. The Crown further argued that the defence at the first trial did not cross-examine $\mathrm{M}$ on the allegation relating to the landlord. Thus it was unlikely that they would have emphasised the allegation of rape at age five. Finally the Crown argued that it was open to the defence at the first trial to explore the allegation of 'an episode of sexual abuse', as it had then been termed, at the age of five, even if they did not know it amounted to an allegation of rape.

HELD, ALLOWING THE APPEAL IN PART, it was necessary in the interests of justice to receive the fresh evidence of the examining doctors. The fresh evidence had 'the ability to undermine the integrity of M's assertion that she was a virgin, in terms of there being no possible previous hymenal injury, and therefore the context in which the medical evidence was placed before the jury at the retrial by the prosecution and so directed by the judge' (at [50]). The court was satisfied that the impact of the fresh evidence was sufficient to throw doubt on the safety of the conviction for rape and quashed it.

The fresh evidence did not affect the safety of the sexual assault convictions. M's virginity was not an issue at the first trial, and the trial judge had directed the jury that the medical evidence was inconclusive. Although the present case was 'broadly similar' to $R$ v DJF [2008] EWCA Crim 2859, there was not the same level of 'intertwining' between the sexual assaults and the rape (at [55]). The jury at the appellant's first trial 'obviously' considered the counts separately (at [55]) and the sexual assault convictions were safe (at [56]).

\section{Comment}

This case has a number of very interesting dimensions, including the prosecution's failure to disclose the examining doctor's notes, and the lack of investigation into what exactly $M$ and the examining doctor understood by the term 'rape'. Indeed, the court commented on the deleterious effects of not exploring the meaning of the term with M (at [37]) and the examining doctor (at [47]). However, the focus of the appeal was on whether the complainant's evidence in relation to the offences was credible, given the inconsistencies between her account at the (re)trial, in which she denied ever having been raped, and her account to the examining doctors and assistant social worker at the time, when she stated she was raped at the age of five.

The importance attached to these inconsistencies was misplaced. The prosecution's decision in the retrial to focus on the medical evidence is at the root of the success of this appeal. The Court of Appeal was 'surprised' at this stance (at [41]). Whatever the reason for it, the decision to focus on the evidence of a hymenal disruption meant that the appellant could tie the complainant's credibility to the issue of virginity. This is clear in the court's holding that the newly disclosed notes 'had the ability to undermine the integrity of M's assertion that she was a virgin, in terms of there being no possible previous hymenal 
injury' (emphasis added) (at [50]). This linking of credibility to a particularly narrow definition of virginity (hymenal disruption) is concerning for a number of reasons.

\section{Rape Myths, Virginity and Credibility}

This case should be read in the light of reforms to the law of evidence regarding the so-called 'rape shield'. The relevance of previous sexual experience has been shown to be often based on outdated stereotypes about women, including the twin myths that a woman's previous sexual activity makes her both more likely to consent to sexual intercourse and less worthy of belief than other women. These myths have been strongly deprecated by the House of Lords ( $R \vee A$ (No 2) [2001] UKHL 25 at [27]). What would have been the value of questioning the complainant about the previous statements regarding the incident when she was five years old? Any questioning on this matter would clearly be related to M's credibility, and would therefore be specifically prohibited under s. 41(4) of the Youth Justice and Criminal Evidence Act 1999. Likewise, the assertion that the evidence would have been admissible because of the inconsistency between the two accounts (of being/not being a virgin) is problematic; arguably it amounts to simply using the complainant's previous sexual experience to attack her credibility.

The examining doctor explained that she used the term 'sexual abuse' in her witness statement to mean 'physical contact, including penetrative (e.g. rape, buggery or oral sex), or non penetrative acts', in accordance with the definition of the Department of Health, Home Office, Education and Employment publication Working Together to Safeguard Children (1999). This was not appreciated by either trial advocate; the Court of Appeal described this 'anodyne descriptive phrase' as unsatisfactory in the circumstances of the criminal investigation and capable of misunderstanding (at [47]). The confusion around what rape meant to the examining doctor means that a finding of possible inconsistency and therefore possibly damaged credibility, is a self-fulfilling prophecy, despite the impossibility of knowing whether M's statements were in fact inconsistent.

Indeed it is difficult to understand where the force of the inconsistency argument lies, given that in the retrial defence counsel asked M (following leave granted pursuant to s. 41(3)(a) YJCEA 1999) about a reference in her interview to an incident involving her landlord when she was a teenager. Counsel argued that the damage to the complainant's hymen was possibly due to her having been raped. M said she had been 'almost raped' by him (at [21]). The trial judge directed the jury that the medical evidence regarding hymenal disruption could only assist them if they accepted M's evidence that she had been a virgin at the time of the alleged rape (at [28]). Surely this evidence and direction would have lead to the jury to consider the possibility of (a) her hymen having already been broken and (b) whether this possibility had any bearing on the value, if any, of the medical evidence.

Furthermore, close examination of the options open to the complainant in talking about her sexual history exposes how the law limited the complexity of her experience. Because of the Crown's decision to focus on the medical evidence regarding hymenal disruption, there was no room for $M$ to say: 'Although my hymen had been ruptured during forced intercourse at the age of five, or through sexual contact with a man when I was a younger teenager, I considered myself to be a virgin, and to never have had sexual intercourse. I did not consider myself as having lost my virginity until the attack by L. I did bleed for three days afterwards, and that may be because my hymen was torn or because the rape was so violent. I don't know.' Neither could she say: 'I don't remember the details of what happened to me at the age of five. Most people do not remember what happened to them at such a young age. I was so upset by the experience I did my best to forget it. I don't know if my hymen was ruptured, but I still considered myself a virgin.' Either of these statements would have drawn accusations of inconsistency with the medical evidence.

The focus on the hymen meant that M's credibility was bound up with medical validation. This mobilised the 'real rape' stereotype, part of which is the idea that 'real rapes' typically cause physical damage (see Kelly et al., A Gap or a Chasm? Attrition in Reported Rape Cases (Home Office Research Study 293: London, 2005). This stereotype is contradicted by the fact that sexual violence is usually carried out 
through implied force and threat and therefore does not leave injuries on a woman's body (see C. White and I. McLean, 'Adolescent Complainants of Sexual Assault: Injury Patterns in Virgin and Non-Virgin Groups' (2006) 13 Journal of Forensic Medicine 172). The search for external medical evidence to legitimate M's story recalls the dark days of the mandatory corroboration warning in sexual offences trials (see $R$ v Baskerville [1916] 2 KB 65).

Finally, this case raises fundamental questions about the relevance of medical evidence pertaining to the hymen. As leading forensic experts have recently stated, 'the status of the hymen has no correlation with previous penetration or sexual contact; it does not enable a determination of whether penetration of the hymen or vagina by a penis or any other object has occurred. An individual with an undamaged hymen may or may not have experienced penetrative sexual contact. There similarly may be no trace of hymenal lesion following sexual assault' (Independent Forensic Expert Group, 'Statement on Virginity Testing' (2015) 33 Journal of Forensic and Legal Medicine 121 at 123). In other words, the presence or absence of the hymen is of no medical diagnostic value, and thus of no probative value in criminal trials. Admitting evidence of hymenal disruption has the potential to distort the fact-finding goal of the trial. In the context of the stubbornly high attrition rates in rape and sexual assault prosecutions (see Stanko et al., 'Complaints of Rape and the Criminal Justice System: Fresh Evidence on the Attrition Problem in England and Wales' (2015) 12(3) European Journal of Criminology 324) this is an issue that deserves considered reflection by practitioners and academics. This case is a timely reminder to prosecutors in particular that the option of 'strengthening' complainant testimony by reference to medical evidence relating to the hymen should be treated with great caution, because it may prove counter-productive.

Sinead Ring

\section{Foreign criminal convictions and character directions $R$ v Benjamin (Mark) [2015] EWCA Crim 1377}

\section{Keywords}

Character, judicial directions, previous convictions, foreign convictions

Following trial at Harrow Crown Court the appellant (B) was convicted of a single count of theft and acquitted of a single count of battery. Both charges arose from an incident which occurred while B was shopping at a Sainsbury's store in Willesden, North West London, with his two children aged six and four. Whilst at the till B placed items which had been scanned into his rucksack before the till developed a problem. B then refused to allow the items to be rescanned and left the store with the items still in his rucksack (at [4]). This formed the basis of the theft charge. Outside of the store B was stopped by a security guard with whom a 'scuffle ensued' during the course of which B 'was alleged to have delivered a blow to the security guard's face' (at [5]) thus forming the basis of the charge of battery. B argued that he had left the store due to 'concerns for his autistic son who was with him' (at [7]). He denied being dishonest or having an intention to permanently deprive, claiming that he had 'intended to put the goods to one side when he got home' (at [7]). B denied committing a battery against the security guard.

At trial it was identified that B had a previous conviction from 2003 for being drunk and disorderly and a conviction from 2009 from the Criminal Court in Nice, France, for assault and assault upon a public officer. A separate conviction for violent disorder was disregarded due to a certificate of conviction not being obtainable. The defendant asserted that the French 'conviction' was in fact closer to what the courts in England and Wales would recognise as a 'bind over' (at [15]) and instructed his counsel 'that 
the 2009 matter did not constitute a conviction' (at [12]). Despite this, no good character direction was sought on his behalf.

Amongst the 26 grounds of appeal originally submitted by B he was granted leave to appeal on only one; specifically whether the trial judge was wrong in failing to give the jury a direction regarding his good character.

HELD, dismissing the appeal, applying s. 74(3) Police and Criminal Evidence Act (PACE) 1984, B's 'assertion that the conviction was akin to a bind-over and did not represent a conviction [was] wholly insufficient to displace the authority of the conviction' (at [16]). On that basis the judge was correct to determine that B was 'not to be regarded as a man of good character and thus ... was not entitled to a good character direction' (at [18]). Although B was subsequently acquitted on the charge of battery it remained 'a live issue for the jury' to consider and thus 'a modified good character direction would not have made sense to the jury and could not properly have been given' (at [20]).

\section{Commentary}

\section{Good Character Directions}

It is a long established common law principle that a defendant is entitled to adduce evidence of his or her good character provided it takes the form of evidence of the defendant's general reputation as a person of good character (see for example $R$ v Rowton 169 ER 1497; $R \vee$ Redgrave (1982) $74 \mathrm{Cr}$ App R 10). Where a defendant is entitled to adduce evidence of good character that evidence is potentially relevant both to the defendant's credibility and to the likelihood of them having committed the offence with which they are charged ( $R \vee$ Vye [1993] 1 WLR 471; $R \vee$ Aziz [1995] 3 All ER 149). Thus in Vye the Court of Appeal identified;

... it must be for the trial judge in each case to decide how he tailors his direction to the particular circumstances... Provided that the judge indicates to the jury the two respects in which good character may be relevant, i.e. credibility and propensity, this court will be slow to criticise any qualifying remarks he may make based upon the facts of the individual case. (at 139)

The standard good character direction therefore has two limbs; a 'credibility limb' which is given where the defendant testifies or relies upon exculpatory statements made out of court (Vye at 476) and a 'propensity limb' to which a defendant of good character will usually be entitled subject to the exercise of the judge's discretion taking into account the facts of the case. Recently the Court of Appeal in $R \mathrm{v}$ Hunter and others [2015] EWCA Crim 631 confirmed that the courts must follow the approach outlined in $R \mathrm{v} V y e$ and $R \mathrm{v} A z i z$ in relation to the provision and form of good character directions (see M. Stockdale, 'Revised Guidance on Good Character Directions' (2015) JCL 79(5), 317-321 at 320 for a more detailed discussion on this point).

In Hunter the Court of Appeal also considered the two categories into which a defendant's good character might fall. A defendant with 'absolute' good character (meaning a defendant with no previous convictions, cautions or proven reprehensible conduct) will usually be entitled to both limbs of the good character direction (credibility and propensity) even if no evidence of good character is adduced by the defence (Hunter at [77]). Alternatively, where a defendant has old, minor or irrelevant previous convictions she may still be said to be of 'effective' good character. In these circumstances the judge 'should be vigilant to ensure that only those defendants who merit an 'effective good character' are afforded one' (Hunter at [79]). If the judge determines that this is the case 'S/he must give both limbs of the [good character] direction, modified as necessary to ... ensure the jury is not misled' (Hunter at [80]).

In the present case the judge correctly determined that B's previous convictions, and in particular the conviction for assault from the Criminal Court in Nice, were relevant to 'a live issue for the jury' (at [20]), namely the charge of battery. In the circumstances B was therefore not a person of 'effective' good 
character and, as such, 'a modified good character direction would not have made sense to the jury and could not properly have been given' (at [20]).

\section{The Admission of 'Foreign' Criminal Convictions}

Foreign criminal convictions admissible in evidence in criminal trials in England and Wales may be proved by virtue of s. 73(1) PACE 1984 which provides:

Where in any proceedings the fact that a person has in the United Kingdom or any other member state been convicted ... of an offence... is admissible in evidence, it may be proved by producing a certificate of conviction...

In respect of European Union member states, Art. 3(1) of Council Framework Decision 2008/675/ JHA creates the following obligation:

Each member state shall ensure that in the course of criminal proceedings against a person, previous convictions handed down against the same person for different facts in other member states, in respect of which information has been obtained under applicable instruments on mutual legal assistance or on the exchange of information extracted from criminal records, are taken into account to the extent previous national convictions are taken into account, and that equivalent legal effects are attached to them as to previous national convictions, in accordance with national law.

The sharing of criminal records information between EU member states is governed by Council Framework Decision 2009/316/JHA, which implemented an earlier Council decision (2009/315/JHA) and led to the creation of the European Criminal Records Information System (ECRIS). Under the ECRIS system, when an individual is convicted of an offence in a jurisdiction which is not that of their country of origin, information relating to that conviction should be transmitted by the member state in which the individual was convicted to the individual's country of origin.

In the United Kingdom the 'designated central authority' (at [13]) for exchanging criminal records is the UK Central Authority for the Exchange of Criminal Records (UKCA-ECR) and they have a duty to store information relating to the foreign criminal convictions of UK citizens. In the present case the Criminal Appeal Office was able, through this mechanism, to obtain a certificate from the UKCAECR detailing the record of B's conviction and the name of the convicting court (at [14]).

In determining that B's conviction by the Criminal Court in Nice was in fact a criminal conviction (rather than something akin to a bind over) the court relied primarily on the information contained in the certificate provided by the UKCA-ECR. In particular the Court of Appeal considered the fact that the penalty imposed on B was 'imprisonment for six months which was suspended for a period of 18 months, coupled with probation or supervision' and the fact that 'the record of conviction will remain on court records for a period of 40 years' (at [14]) as evidence that the conviction was sufficient to displace B's 'effective' good character.

Once it is determined that a criminal conviction is admissible in criminal proceedings, $s$. 74(3) PACE 1984 creates a rebuttable presumption that the convicted person committed the offence of which they were convicted (regardless of the jurisdiction in which they were convicted). In the present case B's 'assertion that the conviction was akin to a bind-over and did not represent a conviction [was] wholly insufficient to displace the authority of the conviction' (at [16]) and thus B failed to discharge the burden of rebutting the presumption of his criminal conviction. 


\section{Houseguests, trespassers and the use of reasonable force in ejectment $R$ v Day [2015] EWCA Crim 1646, Court of Appeal}

\section{Keywords}

Assault occasioning actual bodily harm, common assault, self-defence, ejectment

Edina Day (D) was charged with assaulting Jac Jones (J), occasioning actual bodily harm, contrary to s. 47 of the Offences Against the Person Act 1861 (OAPA). She appeared before HH Judge Cottle and a jury at Bristol Crown Court in June 2014 and entered a plea of not guilty.

In November 2013, D was staying overnight at a friend's student accommodation in Clifton, Bristol. This consisted of a flat comprising three bedrooms, one occupied by D's friend, Hannah Smeaton (S), one by another female, Shubnah Miah, and one by J. The alleged assault occurred in the early hours of the morning when D pushed J out of S's bedroom (where D was going to be sleeping). Over the course of the evening, D, J and S had argued about J playing loud music in his room. Subsequently, while D was in $\mathrm{S}$ 's bedroom getting ready for bed, $\mathrm{J}$ and $\mathrm{S}$ were arguing in the living room. D asked $\mathrm{J}$ to come into the bedroom to talk, but the discussion became heated and $\mathrm{D}$ asked $\mathrm{J}$, who had by his own admission been drinking, to leave S's room. She warned him that if he did not leave, she would shut the door on him. J told the jury that he presumed that she meant leave the flat, and not just the bedroom. He stood his ground, saying he paid rent. At that point, J told the jury "She got up and stood really close to me. She was squaring up to my face. She said "say it again" and with that she pushes me with both hands in the chest, causing me to fall backwards and crack my head on the bathroom door frame.' An ambulance was called and $J$ was taken to hospital where he was given 10 staples to close up a head gash.

HH Judge Cottle directed the jury on self-defence but refused to allow D to also rely on the common law right of householders to use reasonable force to eject trespassers ('ejectment'), because D was only S's guest in the flat. He said, 'She was there as a guest. So I reject that, and say that she has no defence arising from that.' The jury acquitted D of the s. 47 OAPA offence (on the basis that J's injuries were not caused by D's push), but convicted her of common assault. She appealed to the Court of Appeal contending that the defence of ejectment was available to anyone who was in lawful occupation of property.

HELD, ALLOWING THE APPEAL, the judge had been wrong not to allow D to invoke the ejectment defence. That defence was 'not only available to the owner or resident of the place in question, but generally if the relevant person is in lawful occupation. Such a person is entitled to use reasonable force to evict an unwanted trespasser' (at [6]). According to Laws LJ, giving the judgment of the court:

'The jury might well have concluded that this young woman, partly clad at night-time, did no more than seek to eject a drunk from her room. If the judge had directed the jury that $[D]$ was in all the circumstances entitled to use reasonable force to get $[\mathrm{J}]$ out of her bedroom, it is clearly possible that they might have accepted that that was all she did and acquitted her'. (at [9])

\section{Commentary}

\section{Causation in s. 47 OAPA Cases}

It appears that the jury acquitted D of the offence charged on the basis that J's injuries were self-inflicted after J had 'theatrically fallen backwards following what had in fact been a gentle push' (at [3]). The present case therefore illustrates the proposition that the 'daft' or 'unexpected' response of the victim of an assault or battery may be sufficient to break the causal chain in a s. 47 case. As Stephenson LJ explained in $R$ v Roberts (1972) $56 \mathrm{Cr}$ App R 95, in which V jumped from a moving car and sustained injury amounting to actual bodily harm after the driver, $\mathrm{D}$, attempted to remove her coat: 
The test is: Was [actual bodily harm] the natural result of what [D] said and did, in the sense that it was something that could reasonably have been foreseen as the consequence of what he was saying or doing? [If] of course [V] does something so 'daft' ... or so unexpected [such] that no reasonable man could be expected to foresee it, then it is only in a very remote and unreal sense a consequence of his assault, it is really occasioned by a voluntary act on the part of $[\mathrm{V}]$ which could not reasonably be foreseen and which breaks the chain of causation between the assault and the harm or injury.' (at 102).

\section{Ejectment}

The common law defence of ejectment is not one that is frequently invoked but, when it is, the present case confirms that there is no rule of law restricting it to the owner of, or resident in, the property. One of the best-known examples is $R v$ Scarlett [1994] $98 \mathrm{Cr}$ App R 290, in which the accused's manslaughter conviction was quashed on the basis of the trial judge's misdirection to the jury about ejectment. The accused was a landlord in Halifax who had forcibly ejected 'a large, heavily-built man' who was 'the worse for drink' from his pub. This unfortunately culminated in the man's death after he fell down the steps leading up to the front door of the pub and struck his head on the pavement. Beldam LJ, giving the judgment of the Court of Appeal, said:

We are of the opinion that the directions to the jury in the circumstances of this case were inadequate to support a verdict of guilty of manslaughter. The appellant had given clear evidence that he only intended to use sufficient force to remove the deceased from the bar, an act he was lawfully entitled to do.' (at 296)

More recently, in Semple v DPP [2009] EWHC 3241, which also involved the ejection of a drunken man from a pub, this time in Luton, Hickinbottom $\mathbf{J}$ referred to the 'right of a licence holder to eject a customer whom he does not wish to remain on the premises' (at [11]). He then added that '[At] common law an occupier of premises - whether licensed or not-has the right to ask a person to leave and the right to eject him using reasonable force if he refuses' (at [11]; emphasis added).

The Crown in the present case relied on the case of $R$ v Burns [2010] EWCA Crim 1023, [2010] 1 WLR 2694, in support of the proposition that D could not claim the defence of ejectment. In Burns, the accused had been convicted of assault occasioning actual bodily harm after forcibly removing a prostitute from his car as a result of which she suffered scratches and grazes to her legs. He had picked her up in the red light area of Huddersfield, negotiated and paid a fee of $£ 50$ for oral sex, and then driven to a more 'secluded' area when he switched on his car's interior lights and realised that she was somewhat less attractive than she had appeared whilst on the street. He had asked her to get out but, after she had refused, he had (he claimed) used no more than reasonable force to eject her from his car. However, his defence of ejectment (described by Lord Judge CJ as 'self-help') had been rejected by the jury and his conviction was upheld by the Court of Appeal. Laws LJ in the present case pointed out that the defence in Burns had failed because it had not been necessary for the accused to use force at all (instead of dragging the woman out, he could have regained possession of the vehicle by driving her back to the place where he had picked her up), as opposed to the defence not being available to the owner of a vehicle. Laws LJ said that Burns 'does not begin to contradict the proposition that in circumstances such as those in this appeal the lawful occupier of the space in question is entitled to use reasonable force to remove an unwanted trespasser' (at [9]).

\section{Householder Cases under the Criminal Justice and Immigration Act 2008}

D's application for leave to appeal was heard in the Court of Appeal in February 2015. In granting leave, Hallett LJ referred to the ejectment defence as the 'householder defence' ( $R$ v Day [2015] EWCA Crim 253 at [5]). That invites confusion with s. 76(5A) of the Criminal Justice and Immigration Act 2008 (the 
2008 Act). That provision was inserted into the 2008 Act by s. 43 of the Crime and Courts Act 2013 (the $2013 \mathrm{Act})$. Section $76(5 \mathrm{~A})$ of the 2008 Act (as amended) provides:

In a householder case, the degree of force used by $\mathrm{D}$ is not to be regarded as having been reasonable in the circumstances as $\mathrm{D}$ believed them to be if it was grossly disproportionate in those circumstances.

In the present case, Laws LJ said that "the expression "householder defence" appears in section 76 of the [2008 Act]. That of course has no bearing in the present case' (at [4]). However, Laws LJ does not explain why the 'householder defence' would be inapplicable. It is not a question of timing; s. 76(5A) became effective several months before the incident in the present case. The likely explanation is that $\mathrm{s}$. $76(5 \mathrm{~A})$ had 'no bearing' because D was not acting in self-defence. Given the jury's verdict (not guilty under s. 47 OAPA but guilty of common assault), they must have accepted that, whilst D pushed J out of $S$ 's room, she did not do so with sufficient force to cause his injuries. Hence, there was no suggestion that she used disproportionate force; rather, her plea of self-defence was rejected because she was not acting in order to defend herself (but was acting in order to eject a drunken man from her friend's bedroom).

However, had $\mathrm{D}$ been acting in self-defence, and had there been a dispute as to the amount of force used, then it appears that s. $76(5 \mathrm{~A})$ of the 2008 Act would have been applicable. Section $76(8 \mathrm{~A})$ of the 2008 Act (as amended by the 2013 Act) defines 'a householder case':

For the purposes of this section 'a householder case' is a case where -

a. the defence concerned is the common law defence of self-defence,

b. the force concerned is force used by $\mathrm{D}$ while in or partly in a building, or part of a building, that is a dwelling...

c. D is not a trespasser at the time the force is used, and

d. at that time $\mathrm{D}$ believed $\mathrm{V}$ to be in, or entering, the building or part as a trespasser.

The following points should be noted about the scope of the 'householder case'.

Need to be Acting in 'Self-Defence'. Section 76(5A) only concerns 'the common law defence of selfdefence'. At first glance, this appears to rule out cases where the accused was acting in defence of others, for example her children. However, this is not the case: s. 76(10) of the 2008 Act states that 'references to self-defence include acting in defence of another person'. Thus, the accused is entitled to use 'disproportionate' force in protecting themselves and/or other people in a 'dwelling'. However, s. 76(5A) clearly does not apply to the defence of ejectment, hence its unavailability in the present case.

Need To Be In-or Partly In-a 'Dwelling'. The accused must be in, or partly in, a 'building' which is also a 'dwelling'. Clearly, this means that if the accused is in her own home, s. 76(5A) will apply, but it is not a requirement. Hence, if $\mathrm{D}$ is staying as a guest with friends or relatives in their home and uses force against a burglar or trespasser, it will still be classed as a 'householder case'. This aspect of the 'householder' defence would have been satisfied in the present case.

The concept of being 'partly in' a building is undefined in the 2008 Act and may well attract litigation. However, it is clearly designed to deal with cases where the accused uses 'disproportionate' force against a burglar (or attempted burglar) whilst stood in the doorway or other entrance of a dwellingperhaps even whilst leaning out of a window. As long as the accused was at least 'partly' in a building, which is also a 'dwelling', s. 76(5A) will apply.

The Accused Must Not Be a 'Trespasser'. As far as the accused is concerned, they must not be trespassing. They need not be the owner or resident of the dwelling in question, but they must be there lawfully, for example as a guest. This aspect of the 'householder' defence would also have been satisfied in the present case. 
Need to Believe that $\mathrm{V}$ was Trespassing. Although s. 76(5A) is clearly designed to deal with householders who use force against burglars, there is no requirement that $\mathrm{V}$ actually was trespassing, or even that $\mathrm{V}$ was in the building, at the time. It is sufficient that $\mathrm{D}$ believed that $\mathrm{V}$ was in, or was entering, the building as a trespasser. Moreover, s. 76(8D) of the 2008 Act (as amended) states that 'subsections (4) and (5) apply for the purposes of subsection (8A)(d) as they apply for the purposes of subsection (3)'. This means that:

- the accused's belief may be mistaken, even unreasonably mistaken; provided it is a genuinely held (and sober) belief, she can rely upon it (see s. 76(4) of the $2008 \mathrm{Act}$ )

- the accused cannot rely upon a mistaken belief if that belief was induced by voluntary intoxication (see s. $76(5)$ of the 2008 Act).

As far as the present case is concerned, it appears that this element would also have been satisfied. According to D, she had asked J to leave S's bedroom three times but he refused to do so, culminating in her pushing him out of the room. J may therefore have genuinely believed—rightly or wrongly—-that $\mathrm{D}$ was trespassing by refusing to leave S's room.

Finally, it is useful to consider how s. 76(5A) might apply to some of the pre-2008 Act cases involving householders and burglars. In $R$ v Martin [2001] EWCA Crim 2245, [2003] QB 1, the outcome may have been different. In Martin, D's plea of self-defence was rejected and he was convicted of murder (and wounding with intent, contrary to s. 18 OAPA) on the basis that he used excessive force in shooting at two burglars in his home, killing one of them and injuring the other. Under s. 76(5A), D may have been acquitted on the basis that the force used was not 'grossly disproportionate' according to the facts as he believed them to be. In $R$ v Hussain \& Another [2010] EWCA Crim 94, however, the outcome would be exactly the same. In that case, the defendants chased a burglar down the street before attacking him with a cricket bat and other weapons, causing serious injury. The defendants were convicted of causing GBH with intent, contrary to s. 18 OAPA, after their self-defence pleas failed. It is clear that s. $76(5 \mathrm{~A})$ would not alter these verdicts, because it was not a 'householder case'. At the time of the force being used, the defendants were not 'in or partly in a building' (as required by s. 76(8A)(b)) and at 'at the time the force [was] used', the victim was not 'in, or entering, the building or part as a trespasser' (as required by $\mathrm{s} .76(8 \mathrm{~A})(\mathrm{d}))$.

Tony Storey

\section{Declaration of Conflicting Interests}

The author(s) declared no potential conflicts of interest with respect to the research, authorship, and/or publication of this article.

\section{Funding}

The author(s) received no financial support for the research, authorship, and/or publication of this article. 